\title{
Preliminary investigation of the disposition of the molluscicidal saponin deltonin from Balanites aegyptiaca in a snail species (Biomphalaria glabrata) and in mice
}

\author{
Leon BrImer, * Sanaa Hassan ElShEIKH ${ }^{\dagger}$ and Peter FurU ${ }^{\dagger \dagger}$ \\ Department of Veterinary Pathobiology, Faculty of Life Sciences, University of Copenhagen, \\ DK-1870, Frederiksberg C, Denmark \\ ${ }^{\dagger}$ DBL (Danish Bilharziasis Laboratory), WHO Collaborating Centre for Integrated Control of Helminth Infections, \\ Jagersborg, Denmark/University of Khartoum, Graduate College, Sudan \\ ${ }^{\dagger \dagger} D B L$, Jagersborg, Denmark
}

(Received June 5, 2006; Accepted February 7, 2007)

\begin{abstract}
A mixture of deltonin and 25-isodeltonin (approx. 1:1) was found to be the molluscicidal principle in seeds of Balanites aegyptiaca (L.) Del. The disposition in the schistosomiasis vector Biomphalaria glabrata and in mice was studied. Snails were exposed to ${ }^{3} \mathrm{H}$-labelled saponin in water. Administration to mice was oral (O) and intravenous (IV). Snails absorbed the compounds rapidly and showed a high degree of bioaccumulation. The highest concentration was found in the foot followed by the intestines. Snails could excrete the compounds from all organs investigated. Saponin given orally to mice was partly hydrolysed in the intestine, a fraction of genuine and hydrolysed compound being absorbed. Genuine saponin given IV was rapidly distributed to the liver, kidney (medulla), lung and spleen. Compounds did not pass the placenta nor enter the CNS. Excretion was mainly biliary, a minor fraction being excreted in the urine all as genuine compound. About 80\% was excreted within $72 \mathrm{hr}$. While only two (more lipophilic) metabolites were formed in significant amounts by the mice, three such metabolites were seen in extracts of snails. The final toxic agent and the mode of action to target snails remains to be further investigated. (C) Pesticide Science Society of Japan
\end{abstract}

Keywords: $\quad$ molluscicide, deltonin, disposition, Balanites aegyptiaca, Biomphalaria glabrata, mouse.

\section{Introduction}

Schistosomiasis (= bilharzia) is the name of a complex of several vectorborn trematode infestations in $\operatorname{man}^{1)}$ and animals. ${ }^{2)}$ Human infestations are mainly due to three species of blood flukes, i.e. Schistosoma haematobium (endemic in Africa and the Middle East), S. mansoni (Egypt, northern and southern Africa, some West Indies islands, northern two thirds of South America) and S. japonicum (Japan, China, the Philippines, Celebes, Thailand, and Laos). S. mansoni is often seen in Puerto Ricans living in the United States. ${ }^{3)}$

The life history of schistosomes is made up of four components: Two free living but non-feeding larval stages which pass through hypotonic fresh water and two parasitic stages,

\footnotetext{
* To whom correspondence should be addressed.

E-mail: lbr@life.ku.dk

Published online June 27, 2007

(C) Pesticide Science Society of Japan
}

the intermolluscan larval stage during which they reproduce asexually within snails, and adult worms which reproduce sexually in humans. ${ }^{4)}$ A number of species of water dwelling snails are intermediate hosts for these diseases, for example, snails belonging to the genus Bulinus (host of $S$. haematobium) and snails of the genus Biomphalaria (host of $S$. mansoni). Biomphalaria glabrata is the most important host in the Western Hemisphere. ${ }^{1)}$

After asexual multiplication in the snail, the parasite leaves the snail as infective cercariae released into the water. These infect the human host by penetrating the skin. ${ }^{4)}$

Although the prices of effective drugs for treatment such as praziquantel have decreased dramatically since the lifting of the patent, i.e. from around US\$ 3 to US\$ 0.07 per tablet, and thus strengthened the role of control strategies based on treatment instead of eradication of vector snails, ${ }^{5)}$ there still exists a need for effective, water-soluble and safe molluscicides for the latter purpose.

Natural molluscicidal organic compounds include a variety 
of substance classes such as coumarins, ${ }^{6}$ diterpenes, ${ }^{7)}$ alkaloids ${ }^{8)}$ and saponins. ${ }^{9,10)}$ Several saponins were investigated as pesticides for the control of snails, which are vectors for Schistosomiasis. ${ }^{11-13)}$

The desert tree Balanites aegyptiaca (L.) Del. was shown to contain molluscicidal constituents in its different plant parts, ${ }^{14)}$ followed by other species of Balanites. ${ }^{15)}$ This property goes hand in hand with high toxicity, also to fish, ${ }^{16)}$ as is characteristic of saponins. A number of saponins have already been isolated from the fruit mesocarp of B. aegyptiaca ${ }^{17,18)}$ and others from the bark and root. ${ }^{19)}$

The aims of the present study were threefold: (1) to identify the major molluscicidal constituent of the seeds of B. aegypti$a c a$, (2) to study its uptake, distribution and excretion in a mammal species (mouse), and (3) to study its uptake, distribution and excretion in a pesticide target organism (Biomphalaria glabrata). It was considered of great interest to make two parallel disposition studies. Few studies are available of the fate of saponins in mammals. Such data are prerequisites for further toxicological studies, ${ }^{20)}$ if saponins from B. aegyptiaca are to be approved as a pesticide, as demonstrated for constituents of Phytolacca dodecandra. ${ }^{21-27)}$ Knowledge about their disposition in a water-dwelling snail (target organism) on the other hand, can help better understanding of the mechanisms behind - and treatment regimes needed - using saponins to combat of vector snails for bilharzia. A number of non-mammal freshwater living organisms, such as fish, are also vulnerable to the toxicity of many saponins. ${ }^{16)}$

\section{Materials and Methods}

\section{Instruments and chemicals}

Spectra were recorded on the following instruments: NMR (Bruker AC 250 P), IR (Shimadzu FTIR-8100), FAB-MS (Jeol AX $505 \mathrm{~W}$ ). Chemicals were analytical grade from Merck, Darmstadt, Germany. Thin-layer-chromatography (TLC) was carried out using aluminium sheets precoated with Silica Gel 60F 254 (Merck no. 5554).

\section{Isolation and radiolabelling of molluscicidal $\operatorname{saponin}(s)$}

\subsection{Plant material, extraction and purification}

Whole ripe fruits of Balanites aegyptiaca (L.) Del. were sampled from trees in the western part of Sudan. Herbarium samples of leaves and fruits are deposited at the Medicinal and Aromatic Plant Research Institute, Khartoum, Sudan. Ground seeds $(7 \mathrm{~kg})$ were defatted by mechanical pressing. The press cake was percolator extracted at approx. $30^{\circ} \mathrm{C}$ with ethanolwater $(9: 1, \mathrm{v} / \mathrm{v})$. The extract was concentrated in vacuo at $50^{\circ} \mathrm{C}$. Residual oil was extracted with petroleum ether to leave $400 \mathrm{~g}$ of dry "crude saponin." This was extracted several times with methanol-acetone $(60: 40, \mathrm{v} / \mathrm{v})$. Pooled extracts were evaporated in vacuo at $40^{\circ} \mathrm{C}$ to give $141 \mathrm{~g}$ "partly purified crude saponin". Only one major molluscicidal fraction was obtained using four separate steps of bioassay guided ${ }^{25}$ ) column chromatography (Si-gel; mobile phases): (1) $\mathrm{CHCl}_{3}$ / $\mathrm{MeOH} / \mathrm{H}_{2} \mathrm{O}$ (6:6:1), (2) $\mathrm{CHCl}_{3} / \mathrm{MeOH} / \mathrm{H}_{2} \mathrm{O}$ (6:4:1), (3) $\mathrm{CHCl}_{3} / \mathrm{MeOH} / \mathrm{H}_{2} \mathrm{O}(6: 3: 1$; lower phase), and (4) EtOAc/ $\left(\mathrm{CH}_{3}\right) \mathrm{CO} / \mathrm{MeOH} / \mathrm{CHCl}_{3} / \mathrm{H}_{2} \mathrm{O}(40: 30: 12: 10: 8)$.

\subsection{Assay for molluscicidal effect of fractions}

For each fraction/compound and concentration (see below) the assay was as follows: $200 \mathrm{ml}$ of aqueous solution and five seemingly healthy snails (Biomphalaria glabrata) $(6-10 \mathrm{~mm})$ were used and the exposure time was $24 \mathrm{hr}$. Snails recovered from the test solution after $24 \mathrm{hr}$ in $200 \mathrm{ml}$ of water were inspected. Criteria of death were inactivity, discolouration and (in the case of doubt) foul odour upon crushing. ${ }^{28)}$ Each experiment was duplicated. A control was carried out using water with the same resulting concentration of dimethylsulfoxide (DMSO; see below). Each dry chromatographic fraction was dissolved in DMSO and diluted with water to give a $100 \mathrm{ppm}$ solution (DMSO concentration less than 1\%). The assay was carried out at $100 \mathrm{ppm}$. For molluscicidal pure compound(s) isolated $\mathrm{LC}_{50}$ and minimum $\mathrm{LC}_{100}$ were estimated using factor 2 serial dilutions of $100 \mathrm{ppm}$ solution.

\subsection{Compound identification}

Identification was by means of ${ }^{13} \mathrm{C}$ NMR (including DEPT spectra at 90 and $135^{\circ}$ ), TLC analysis of the mixture obtained upon enzymatic hydrolysis using crude enzymes from Helix pomatia snail, enzymatic assay to prove the D-form of isolated glucose moieties and Fast Atom Bombardment Mass Spectrometry (FAB-MS) with dithiothreitol : dithioerythritol $(5: 1)$ as a matrix to give the molecular weight. The isolate was found to be a mixture of deltonin $(25 R)$ and isodeltonin $(25 S)$. ${ }^{13} \mathrm{C}$ NMR signals (pyridine- $d_{5}$ ) for the isolated compound $(R / S)$ and deltonin ${ }^{29,30)}$ (in brackets): $\mathrm{C}_{1}-\mathrm{C}_{27} \delta 37.5$ (37.6), 30.1 (30.0), 78.1 (78.5), 38.9 (39.0), 140.8 (141.0), 121.8 (121.8), 31.8 (32.3), 32.2 (31.9), 50.3 (50.5), 37.2 (37.3), 21.1 (21.2), 39.9 (40.0), 40.5 (40.5), 56.6 (56.8), 32.3 (32.4), 81.1/81.2 (81.2), 62.9/61.9 (62.8), 16.4 (16.3), 19.4 (19.2), 41.9/42.5 (42.1), 15.1/14.9 (15.0), 109.3/109.8 (109.3), 31.7/ 22.7 (31.9), 30.0/26.2 (29.4), 30.6/26.4 (30.7), 66.9/65.1 (67.0), 17.3/16.4 (17.3); glucose moieties G 1-6 $\delta 100.0$ (100.0), 77.8 (78.0), 76.2 (76.0), 82.1 (82.0), 77.3 (77.5), 62.6 (62.0); G 1'-6' $\delta 105.2$ (105.0), 75.0 (75.0), 78.3 (78.0), 71.2 (71.3), 78.5 (77.5), 62.1 (62.5); rhamnose moiety R 1-6 $\delta$ 101.8 (101.5), 72.5 (72.0), 72.8 (72.5), 74.2 (74.0), 69.5 (69.0), 18.7 (18.5). FAB-MS $m / z$ : 907 and $885\left(\mathrm{M}+\mathrm{Na}^{+} \&\right.$ $\left.\mathrm{M}+\mathrm{H}^{+}\right), 739\left(\mathrm{M}+\mathrm{H}^{+}-146\right.$; deoxyhexose $), 723\left(\mathrm{M}+\mathrm{H}^{+}\right.$ -162 ; hexose $), 415\left(\mathrm{M}+\mathrm{H}^{+}-470 ; 2\right.$ hexose +1 deoxyhexose). In accordance with the proposed structure, the mixture obtained after hydrolysis in $2 \mathrm{~N} \mathrm{HCl} / 50 \%$ dioxane $(1: 1)^{19)}$ gave spots on TLC (Si-gel with 15\% EtOAc in benzene as mobile phase) corresponding to both diosgenin and yamogenin, and at nearly the same intensity. The mean ratio of $(R-$ and $S$ ) signal intensities of the ${ }^{13} \mathrm{C}$ NMR spectrum (C-16 to $\mathrm{C}$ 27) was $1.2,{ }^{29)}$ while a $1: 1$ ratio was estimated from the signals at 900 and $920 \mathrm{~cm}^{-1}$ in the IR-spectrum. ${ }^{29)}$ In conclusion, deltonin/25-isodeltonin (approx. 1:1), both compounds de- 
scribed earlier, ${ }^{29-32)}$ was the molluscicidal agent isolated. ${ }^{3} \mathrm{H}$-deltonin/25-isodeltonin was prepared by Amersham Labs., England, by oxidation with morpholine- $N$-oxide and tetrapropyl-ammonium-perruthenate followed by reduction using sodium-boro- $\left({ }^{3} \mathrm{H}\right)$-hydride (personal information; Amersham Labs.). The reaction product was purified by preparative TLC (Si-gel with 1-butanol/ $\mathrm{H}_{2} \mathrm{O} / \mathrm{HOAc}(12: 5: 3)$ as mobile phase), identified by FAB-MS and investigated for purity by TLC. Specific activity and radiochemical purity were $614 \mathrm{Gbq} / \mathrm{mmol}(16.6 \mathrm{Ci} / \mathrm{mmol})$ and approx. $87 \%$, respectively.

\section{Animals}

Pigmented NDF1 mice $\left(\mathrm{F}_{1}\right.$ hybrids between females of the outbreed stock NMRI and males of the inbred strain DBA/2J), were used. Male- as well as non-mated female mice (b.w. approximately $20 \mathrm{~g}$ ), as well as mid-pregnancy (18 days) and late pregnancy (22 days) females were all obtained from Bomholdtgaard Breeding and Research Centre, Denmark. Mice were housed in plastic cages with a $12 \mathrm{hr}$ dark cycle, fed a standard pellet diet and given water ad libitum. Biomphalaria glabrata snails were $10-20 \mathrm{~mm}$ in size, i.e. a little bigger than used for toxicity test during compound purification, and were obtained from the Danish Bilharziasis Laboratory (WHO Collaborating Centre), Charlottenlund, Denmark. The snails were maintained in distilled water with $0.104 \mathrm{~g}$ of $\mathrm{CaCl}_{2}$ and $0.26 \mathrm{~g}$ of $\mathrm{MgSO}_{4}: \mathrm{H}_{2} \mathrm{O}$ per litre (snail water) at $23-25^{\circ} \mathrm{C}$, with a light-dark cycle of $12 \mathrm{hr}$. Snails were fed dried lettuce.

\section{Biological experiments}

4.1. Compound administration and tissue preparation (mice)

Mice were given ${ }^{3} \mathrm{H}$-labelled compound $(0.15 \mu \mathrm{Ci}$ in $70 \%$ ethanol) as a single intravenous (IV) bolus injection of $0.2 \mathrm{ml}$ in a tail vein (corresponding to approx. $400 \mu \mathrm{g} / \mathrm{kg} \mathrm{b.w.)} \mathrm{or}$ they were given the same dose orally by gastric intubation. Animals were placed separately in a normal plastic cage or a metabolic cage. After a predetermined time, the animal was either decapitated (metabolic cage studies) or anaesthetized with ether, rapidly frozen in a bath of acetone/dry ice and mounted in aqueous $2 \%$ carboxymethylcellulose. Freeze-sectioning: thickness $40 \mu \mathrm{m}$ for autoradiography and $60 \mu \mathrm{m}$ for sampling for liquid scintillation counting.

\subsection{Autoradiography (mice)}

Freeze-dried $40 \mu \mathrm{m}$ sections on tape were pressed against Xray films (Hyperfilm-3H, Amersham, England), exposure time of three months.

\subsection{Metabolic cages studies (mice)}

Mice dosed IV were sacrificed after $72 \mathrm{hr}$, while two dosed orally were allowed to live for $96 \mathrm{hr}$. Urine and faeces were collected at times (post admin.): 2, 4, 6, 24 and $72 \mathrm{hr}$ (IV), and $96 \mathrm{hr}$ (per os).

4.4. Uptake and excretion studies (snails)

Six groups of four snails were exposed to $3.75 \mu \mathrm{Ci} / \mathrm{ml}$
(0.2 ppm) of labelled compound in snail water for $10,30 \mathrm{~min}$, 1, 4, 12 and $24 \mathrm{hr}$, respectively. The intestine, hepato-pancreas, kidney, reproductive tract, ovotestis and foot were dissected under a microscope. For each time and organ, pooled tissues were homogenized, and aliquots taken for liquid scintillation counting and chromatographic analysis, respectively. For studies of subsequent excretion, another batch of 28 snails was exposed to $1.88 \mu \mathrm{Ci} / \mathrm{ml}$ for $24 \mathrm{hr}$. The lower dose was used to ensure that the concentration in the clean recovery (excretion) water did not rise significantly during the start of the excretion phase, and inhibited further excretion. After $24 \mathrm{hr}$ the snails were subdivided into groups of four animals. Each group recovered in $200 \mathrm{ml}$ of snail water for $0,1,4,12$, 24, 48 and $72 \mathrm{hr}$, after which they were treated as described above.

4.5. Liquid scintillation counting (mice and snails) Mouse and snail organs, and faeces and urine from mice were analysed. Faecal samples were dried at $100^{\circ} \mathrm{C}$ and comminuted. To $20 \mathrm{mg}$ of sample $100 \mu \mathrm{l}$ of water was added for $30 \mathrm{~min}$ of rehydration. After $1 \mathrm{ml}$ of Soluene 350 had been added, samples were incubated at $50^{\circ} \mathrm{C}$ for $48 \mathrm{hr}$. Following cooling, $0.5 \mathrm{ml}$ of isopropanol and $0.2 \mathrm{ml}$ of $\mathrm{H}_{2} \mathrm{O}_{2}(35 \%)$ were added to decolorize. Samples were counted (after $48 \mathrm{hr}$ of equilibration) using $10 \mathrm{ml}$ of a Hionic Flour scintillator (Packard). Weighed tissue samples of approx. $10 \mathrm{mg}$ (from snail dissections or fresh $60 \mu \mathrm{m}$ sections of mice) were added to $100 \mu \mathrm{l}$ of water and $1 \mathrm{ml}$ of Soluene 350, and further treated as faecal samples. To urine was added $10 \mathrm{ml}$ of scintillator.

\subsection{Chromatographic analysis}

TLC studies were done on mouse urine as well as on extracts of stools and the following snail organs: intestine, hepato-pancreas, foot and reproductive tract. Extracts were prepared by adding $5 \mathrm{ml}$ of a mixture of water and EtOAc (1:1) per gram of material followed by shaking for $1 \mathrm{hr}$ and centrifugation-to separate phases. Both the water and organic phase were analysed on pre-coated silica plates using ethyl-acetate: acetone: methanol: chloroform: $\mathrm{H}_{2} \mathrm{O}(40: 30: 12: 10: 8)$ as mobile phase. ${ }^{33)}$ The labelled genuine compound was applied as standard at 0.6 and $3.0 \mu \mathrm{Ci}$. Chromatograms were visualized based on the radioactivity of spots, using the same technique as for sections from autoradiography.

\section{Results}

Deltonin/25-isodeltonin (approx. 1:1) was identified as the major molluscicidal principle in the seeds of Balanites aegyptiaca (L.) Del. collected in Sudan. The compounds are steroidal spirostanol glycosides (oligospirostanosides).

\section{Snails}

The $\mathrm{LC}_{50}$ was approx. $2 \mathrm{ppm}$ and the minimum $\mathrm{LC}_{100}$ was found to be between 5 and 10 ppm (curve not shown). Subsequent disposition studies used a concentration of $0.2 \mathrm{ppm}$ or lower. The result of a 24-hr uptake study, from a $0.2 \mathrm{ppm}$ 


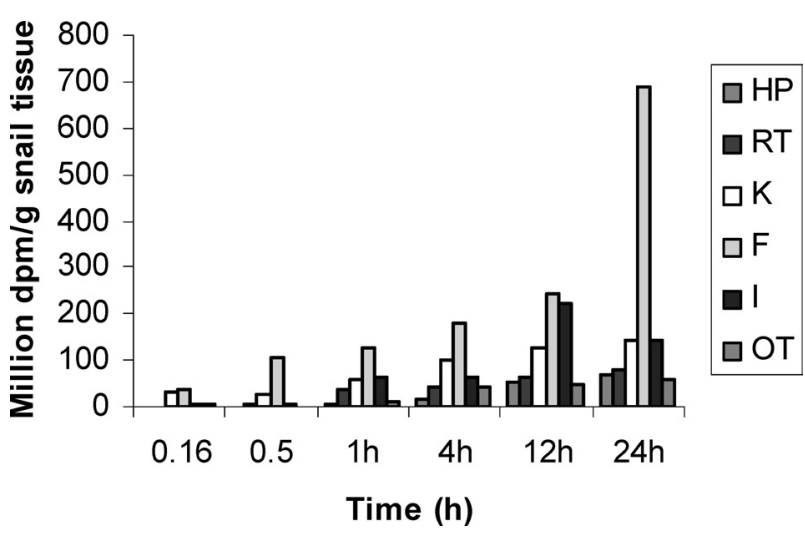

Fig. 1. Radioactivity in snail tissues after different times of incubation in $0.2 \mathrm{ppm}$ of labelled deltonin/25-isodeltonin (uptake study). Symbols denote: HP (hepato-pancreas), RT (reproductive tract), K (kidney), F (foot), I (intestines), OT (ova-testis).

aqueous solution of ${ }^{3} \mathrm{H}$-labelled compound, in Biomphalaria glabrata is shown in Fig. 1. An identical experiment using $0.1 \mathrm{ppm}$ gave rise to very similar relative tissue distribution, the resulting activities being around half of those obtained at the $0.2 \mathrm{ppm}$ level (results not shown). In both experiments, overall radioactivity in the body rose throughout the whole exposure period. This was also the case for each of the organs separately analysed, i.e. the hepato-pancreas, reproductive tract, kidney, foot, intestines and ova-testis; however, organs showed very different affinities to the agent (Fig. 1). Thus, activity in the foot was constantly the highest, and at most times close to double the activities seen in any other organs. Gradu- ally, the activities in the kidney and then also the intestines increased, at times reaching levels between 50 and $90 \%$ of that seen in the foot; however, at $24 \mathrm{hr}$, the activity in the foot dominated the distribution picture (Fig. 1). The strong dominance of the activity in the foot was less pronounced in the $0.1 \mathrm{ppm}$ experiment (Fig. 3, $0 \mathrm{hr}$ ). In tissues from snails exposed for $24 \mathrm{hr}$ (at $0.2 \mathrm{ppm}$ ), about $50 \%$ of the labelling was due to the parent compound, the rest of the activity being found as three chromatographically well separated $\left(\mathrm{R}_{f}: 0.47\right.$, 0.49 and 0.53 ; parent compound 0.35 ) slightly more lipophilic metabolites, as envisaged from TLC analysis (Fig. 2).

When snails exposed to the low-dose $0.1 \mathrm{ppm}$ level for $24 \mathrm{hr}$ were transferred to fresh water, excretion started immediately and continued up to at least $12 \mathrm{hr}$. Quite rapidly during the excretion process, the relative activities found in the different investigated organs reached more or less the same level. Under the batch conditions used (no water change), a steady state was reached in the organs investigated after about 24 hr (Fig. 3).

\section{Mice}

The results of distribution studies after IV administration to mice (female: non-mated, early pregnant and late pregnant; male) are summarized in Table 1, while Figs. 4 and 5 show selected autoradiograms of a non-mated female mouse $4 \mathrm{hr}$ after dosing by IV and orally, respectively. Being a preliminary study to guide further detailed risk assessment studies in mammals, a single animal set-up per time/administration was used. Comparing the organ distribution seen in IV- administered animals $20 \mathrm{~min}$ (when immediate distribution has oc-

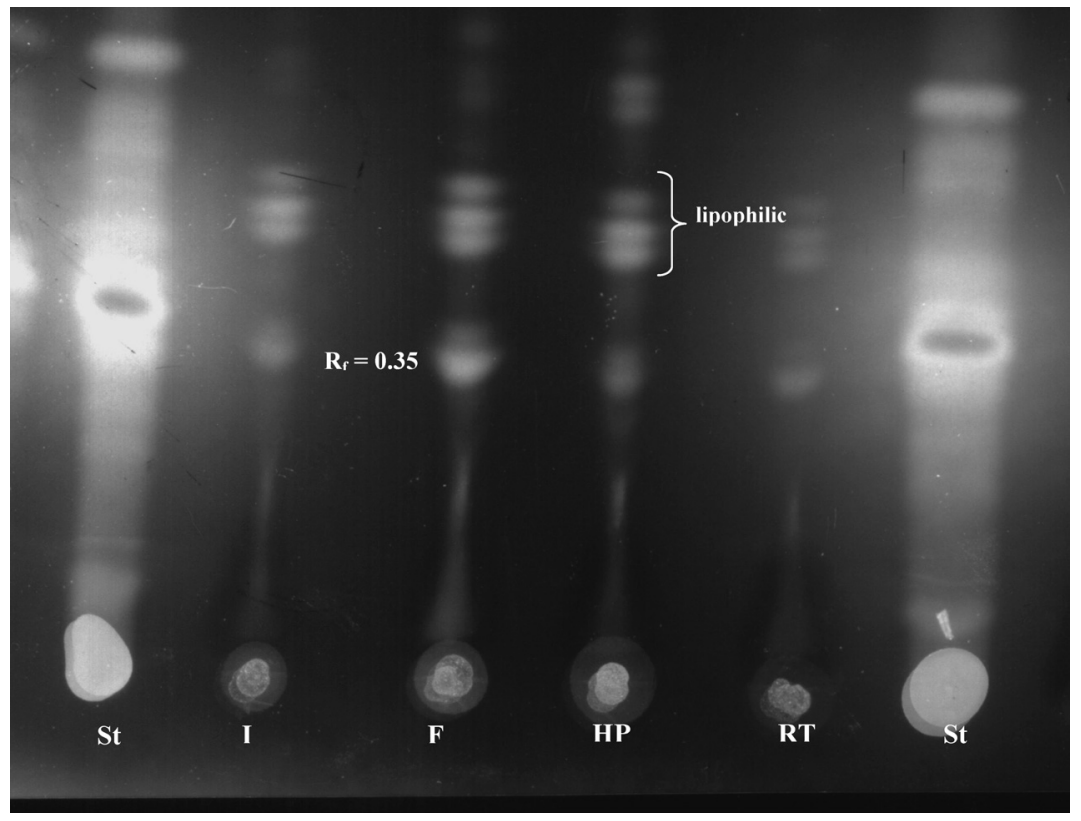

Fig. 2. Thin-layer chromatogram of extracts (water phase) of different tissues of snails exposed to ${ }^{3} \mathrm{H}$-deltonin/25-isodeltonin. Symbols denote: St (standard; major spot at $\mathrm{R}_{f}=0.35$ equal to the component deltonin/25-isodeltonin), I (intestine), F (foot), HP (hepato-pancreas), RT (reproductive tract). 


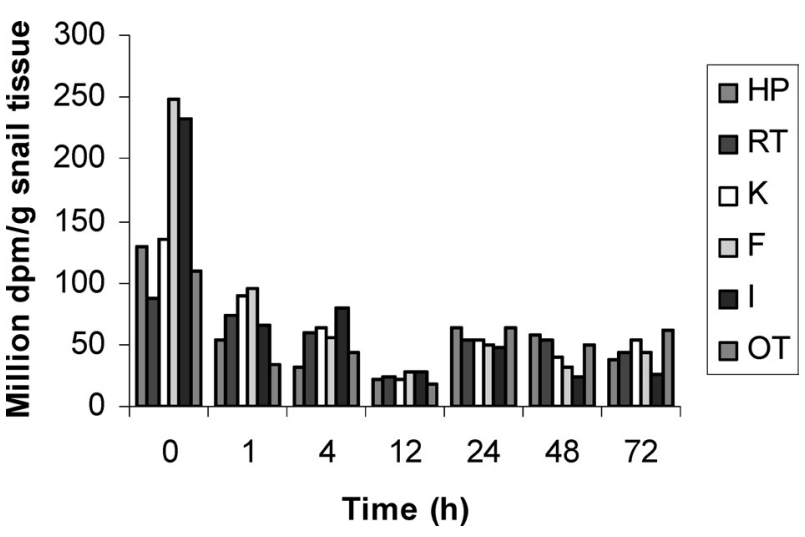

Fig. 3. Remaining radioactivity in snail tissues after different times of recovery in pure water (excretion study). Symbols denote: HP (hepato-pancreas), RT (reproductive tract), K (kidney), F (foot), I (intestines), OT (ova-testis).

curred) and $4 \mathrm{hr}$ after dosing, respectively, i.e. ignoring sex and mating differences, the overall relative distribution of activity between central organs such as the liver, kidneys, lung, heart, brain and spleen are close to identical; however, after $20 \mathrm{~min}$ there is an overall tendency of significant but varying labelling in the lung, stomach and intestines, the rest of the organs showing more constant relative distribution of liver $\geq$ kidney $\geq$ hear $\geq$ brain $\approx$ spleen (Table 1 ). At $4 \mathrm{hr}$, labelling in the lungs in general had decreased significantly while the activity found in the stomach and the intestines still are significant but varying, the distribution between the rest of the organs is as follows: liver $\geq$ kidney $\geq$ lung $\approx$ heart $\geq$ brain $\approx$ spleen (Table 1). Even at 4 days after IV administration, significant labelling is seen in the intestines, liver, kidneys, lung, heart and stomach (Table 1). Autoradiograms of orally dosed females indicated a very high activity in the stomach and intestines ( $20 \mathrm{~min}, 4 \mathrm{hr}$ ) but after $4 \mathrm{hr}$ also showed considerable labelling of the liver and kidneys, some genuine or transformed compound clearly being absorbed (Fig. 5).

The results of the quantitative excretory studies are illustrated in Fig. 6. Within the first $6 \mathrm{hr}$ about $10 \%$ of the activity injected IV as ${ }^{3} \mathrm{H}$-deltonin $/ 25$-isodeltonin was excreted in the faeces and a similar amount in the urine. The mice excreted approx. $80 \%$ (78.4) of the total activity within $72 \mathrm{hr}$, the main proportion $(67 \%)$ by the faecal route and $11.4 \%$ in the urine (Fig. 6).

Chromatograms of the water and EtOAc phases, respectively, from the extraction of faeces of mice after IV administration, proved about $50 \%$ of the labelling to be excreted in faeces as the parent compound, the other approx. $50 \%$ being assigned to two slightly more lipophilic substances $\left(\mathrm{R}_{f}\right.$-values: 0.50 and 0.60 ; parent compound 0.35 , TLCs not shown). The less important urinary excretion consisted of the parent compound only, since no other spots were detected on the chromatograms made from the EtOAc phase (TLC not shown) or the water phase (Fig. 7). For oral administration, the result for faeces was about the same as for IV; however, a different pattern were seen for the urine, where both the parent compound and at least two $\left(\mathrm{R}_{f}\right.$-values: 0.56 and 0.63 ; parent compound 0.35 ) slightly more lipophilic metabolites were also found (TLCs not shown). Both parent saponin and metabolites formed in the gastrointestinal tract were thus ab-

Table 1. Tissue distribution of radioactivity at different time intervals after intravenous injection of a single dose of $8 \mu \mathrm{g}(0.15 \mu \mathrm{Ci})$ of ${ }^{3} \mathrm{H}$-deltonin/25-isodeltonin in mice ${ }^{a), b}$

\begin{tabular}{|c|c|c|c|c|c|c|c|c|c|c|c|c|}
\hline \multirow{2}{*}{ Tissue } & \multicolumn{2}{|c|}{ Exposure time $^{c /} /$} & \multicolumn{4}{|c|}{ Female mice (non-pregnant) } & \multicolumn{2}{|c|}{ Male mice } & \multicolumn{2}{|c|}{ Early pregnancy } & \multicolumn{2}{|c|}{ Late pregnancy } \\
\hline & $5 \mathrm{~min}$ & $20 \mathrm{~min}$ & $1 \mathrm{hr}$ & $4 \mathrm{hr}$ & $24 \mathrm{hr}$ & 4 days & $20 \mathrm{~min}$ & $4 \mathrm{hr}$ & $20 \mathrm{~min}$ & $4 \mathrm{hr}$ & $20 \mathrm{~min}$ & $4 \mathrm{hr}$ \\
\hline Intestine & 440 & 2289 & 6449 & 19984 & 3816 & 539 & 1513 & 410 & 454 & 2159 & 643 & 3381 \\
\hline Liver \# & 1986 & 3796 & 4541 & 9040 & 17139 & 992 & - & 3280 & 1301 & 2386 & 1387 & 4575 \\
\hline Kidney & 1052 & 1900 & 1693 & 3434 & 33965 & 1317 & 1482 & 2426 & 938 & 1950 & 752 & 2387 \\
\hline Lung\# & 532 & 13534 & 763 & 2213 & 23411 & 349 & 62869 & 1248 & 562 & - & - & - \\
\hline Brain & 283 & 413 & $<100$ & $<100$ & $<100$ & $<100$ & $<100$ & $<100$ & $<100$ & $<100$ & $<100$ & $<100$ \\
\hline Heart & 420 & 510 & 1368 & 376 & 1272 & 369 & 916 & 709 & 183 & 1285 & 776 & 304 \\
\hline Stomach & 247 & 10895 & 1356 & 4231 & 1583 & 1175 & 549 & 820 & 4058 & 5212 & 1785 & 1363 \\
\hline Spleen\# & 1107 & 2185 & - & - & - & - & - & - & - & - & - & - \\
\hline Muscle\# & 16042 & - & - & - & - & - & - & - & - & - & - & - \\
\hline Foetus & & & & & & & & & $<100$ & $<100$ & $<100$ & $<100$ \\
\hline Placenta & & & & & & & & & 182 & $<100$ & 422 & 141 \\
\hline
\end{tabular}

\footnotetext{
${ }^{a)} \mathrm{dpm} / \mathrm{mg}$ of tissues. ${ }^{b)}(-)$ means no activity above background detected. ${ }^{c)}$ As defined by period from administration to death.
} 


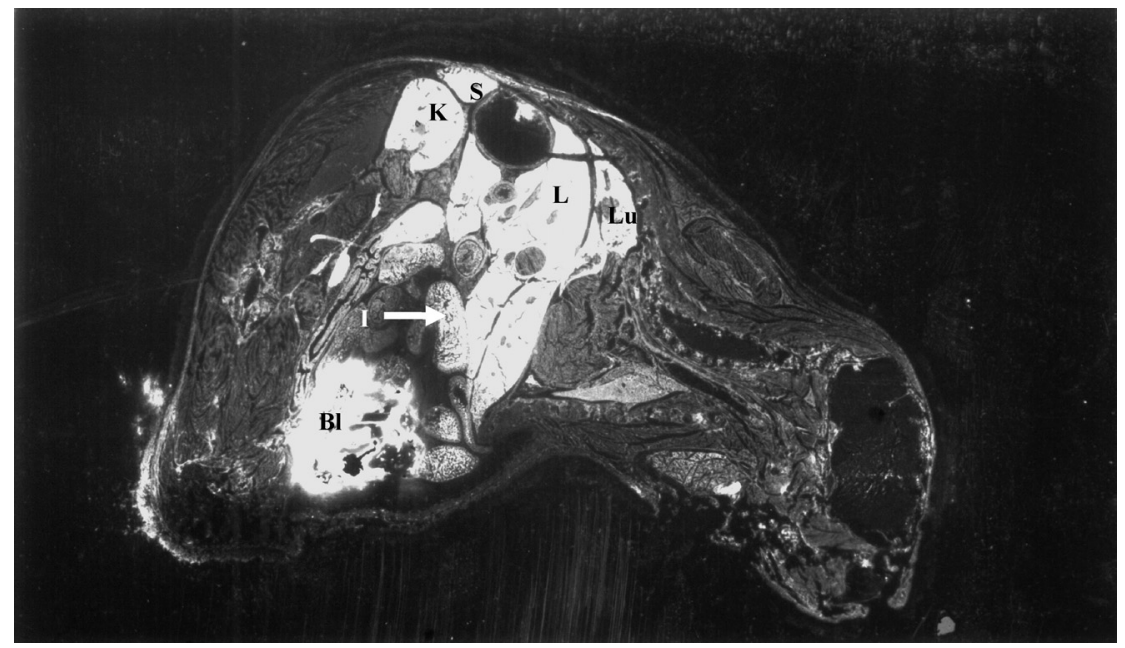

Fig. 4. Whole-body autoradiogram of a non-mated female mouse $4 \mathrm{hr}$ after intravenous injection (IV) of ${ }^{3} \mathrm{H}$-deltonin/25-isodeltonin. Symbols denote: K (kidney), S (spleen), L (liver), Lu (lung), Bl (bladder), I (intestines).

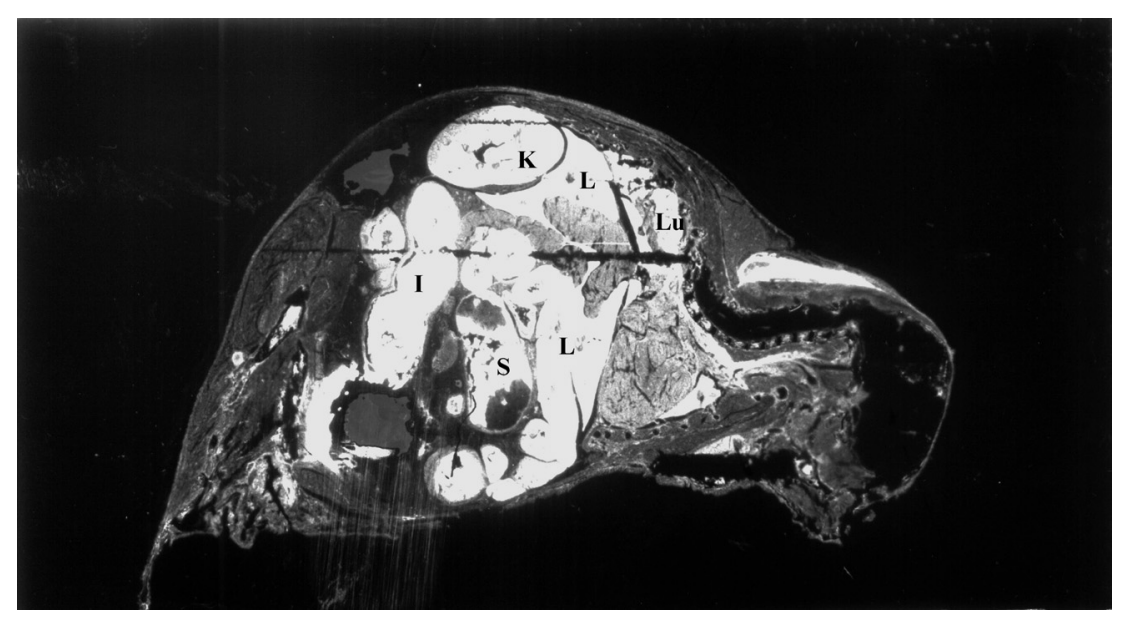

Fig. 5. Whole-body autoradiogram of a non-mated female mouse $4 \mathrm{hr}$ after oral administration of ${ }^{3} \mathrm{H}$-deltonin/25-isodeltonin. Symbols denote: K (kidney), L (liver), Lu (lung), I (intestines), S (stomach).

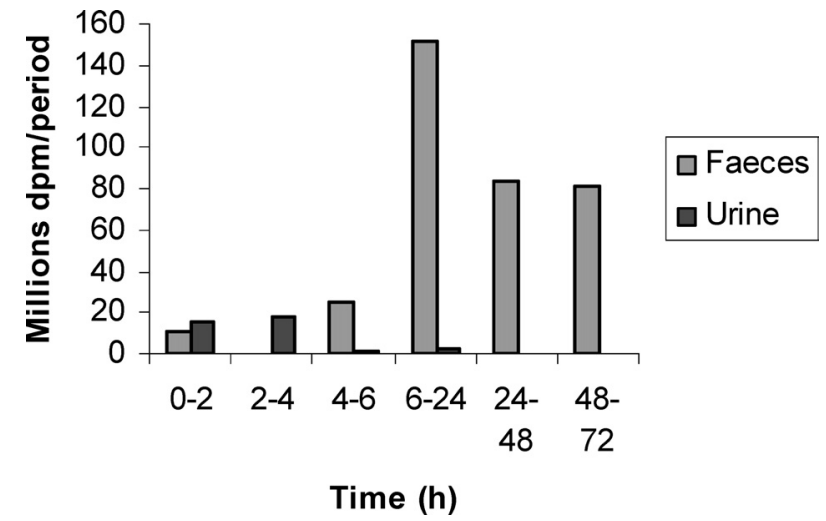

Fig. 6. Mean excretion of radioactivity from labelled deltonin/25isodeltonin and its metabolites in faeces and urine of four female mice during different time intervals after intravenous administration. sorbed and excreted in the urine.

\section{Discussion}

Deltonin/25-isodeltonin was originally isolated and its structure elucidated from Dioscorea deltoidea and has also been shown as present in cell suspensions of this species. ${ }^{31,32)}$ It was found in the stem bark of Balanites roxburghii in a search for insect antifeedant compounds. ${ }^{29)}$ It has not peviously been shown to possess molluscicidal activity, as have on the other hand a number of structurally closely related saponins. ${ }^{17-19)}$

\section{Snails}

Most molluscicidal compounds have been subjected only to very limited investigations concerning their disposition, their more detailed effect(s), and their mode of action in the target $\operatorname{organism}(\mathrm{s})$.

Many glycosides with a steroidal or a pentacyclic triterpene 


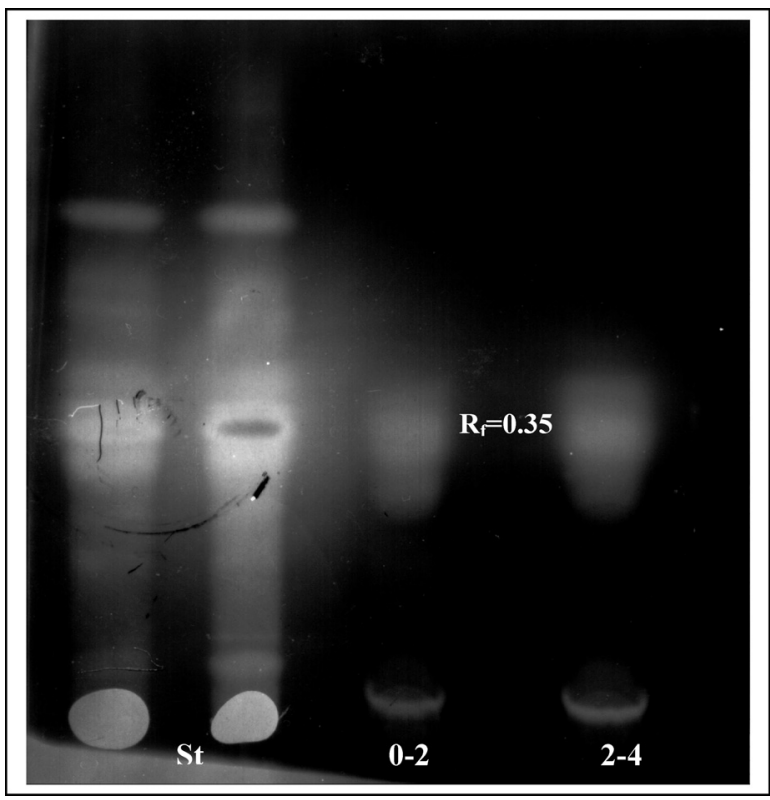

Fig. 7. Thin-layer chromatogram of extracts (water phase) of urine samples from mice given ${ }^{3} \mathrm{H}$-deltonin/25-isodeltonin by the intravenous route. Symbols denote: St (standard; major spot at $\mathrm{R}_{f}=0.35$ equal to the component deltonin/25-isodeltonin), 0-2 (urine pooled over the period $0-2 \mathrm{hr}$ after administration), and 2-4 (urine pooled over the period $2-4 \mathrm{hr}$ after administration).

genin are molluscicidal at low concentrations. Within this group of saponins, saponin-like compounds and steroidal alkaloids some, although restricted, knowledge has been gained concerning the structural demands for their activity, as also for their effects on cell membranes. ${ }^{13,34)}$ Nevertheless, Francis et al. recently concluded that "the precise details of the interactions between saponins and membranes need more elucidation so that the molecular mechanisms involved could be better understood." 13$)$

Concerning their disposition in target vector snails and in mammals, only a study on aridanin ${ }^{20)}$ exists and can be used for comparison. This study also uses the vector snail $B$. glabrata. $^{20)}$

Comparing the uptake and distribution of deltonin/25isodeltonin with the patterns seen for aradanin, ${ }^{20)}$ both differences and similarities are seen. In the present study, the concentration in the foot was constantly the highest and rose throughout the $24 \mathrm{hr}$ of incubation (Fig. 1). In the aridanin study, the concentration in the foot also showed the relative highest concentration among the organs at most measurement points during the $24 \mathrm{hr}$; however, it peaked after $1 \mathrm{hr}$ of exposure after which it found a constant level at around half that seen at $1 \mathrm{hr}$. After $24 \mathrm{hr}$ of constant exposure ( $0.2 \mathrm{ppm}$ in both studies) the relative distribution of compound concentration between the different organs was as follows in the two studies [deltonin (this study)/aridanin ${ }^{20)}$ ]: $\mathrm{F} / \mathrm{F} \geq \mathrm{I} / \mathrm{I} \geq \mathrm{RT} / \mathrm{HP} \geq \mathrm{HP} / \mathrm{RT} \geq$ OT/OT (abbreviations as explained in Fig. 1). The excretion process closely follows that of aridanin. Both studies show a minimum overall content of around $1 / 10$ of the start concentration in the snails after $12 \mathrm{hr}$, all organs showing a considerable decrease in radioactivity (ref. 20 and Fig. 2). The snail metabolises the compound(s) by the action of surface-linked enzymes or after uptake. The identity of the metabolites remains to be established. Hydrolytic cleavage of sugar moieties to give more lipophilic compounds seems to be a reasonable explanation. It seems logical that partial or total hydrolysis of the genuine saponin(s) may mean a reduction of molluscicidal activity. ${ }^{13)}$ In the study on aridanin, the snail converted the glycoside to more lipophilic substances. ${ }^{20)}$

\section{Mice}

In general, the results from counting on tissues, analysis by autoradiography and TLC analysis of excretions support each other concerning the conclusion on the disposition of deltonin-25-isodeltonin in the mouse. After $4 \mathrm{hr}$, the picture seen for IV administration was entirely dominated by biliary excretion as evidenced by the very high labelling of the intestines/ intestinal contents (Table 1). This is in agreement with the fact that the majority of labelling after IV administration was excreted through the faecal route (Fig. 6). The fact that considerable labelling was still seen in all major organs except the brain and spleen 4 days after IV administration (Table 1) further points to the possibility of considerable enterohepatic circulation, maybe mostly of the more lipophilic metabolites found in the faeces. Dominating biliary excretion is in accordance with earlier findings for $\operatorname{aridanin}^{20)}$; however, it seems that higher oral uptake occurs with deltonin/25-isodeltonin than seen for aridanin. Another difference is seen in that only more hydrophilic metabolites (than genuine aridanin) were detected in both the urine and the faeces after IV administration of the compound, ${ }^{20}$ while this study in general showed the formation of more lipophilic metabolites.

No radioactivity was generally detected in the CNS throughout the total study period, as also seen for aridanin. ${ }^{29)}$ Importantly, this observation also holds for oral administration with its uptake of both genuine compound and partially hydrolysed more lipophilic constituents. Labelling did not show any affinity to melanin, i.e. neither the eyes nor skin showed any significant labelling. Also, the present study gave no results to indicate any substantial differences between the two sexes.

For pregnant mice, no (or very low) radioactivity was found in the foetus although faint labelling was seen in the placenta (Table 1). These results were confirmed by autoradiograms of pregnant mice after $4 \mathrm{hr}$ of exposure (not shown). Again, the results are in accordance with those earlier reported for aridanin. $^{20)}$

Although the formation of more lipophilic metabolites was seen for mice as well as snails, clearly nothing more specific can be said about their identity. The two metabolites detected in the faeces of both IV and orally administrated mice may be identical to the urine metabolites of orally fed mice. Theoreti- 
cally, two of the three snail metabolites may be identical to the compounds formed in mice.

\section{Conclusion}

In conclusion, the compound and other lipophilic metabolites are accumulated by the snail Biomphalaria glabrata when exposed in water. If exposed to sublethal concentration-time combinations the snail is able to subsequently excrete the compound with a concentration decrease in all investigated organs. The highest concentration is always found in the foot, which may be used in studies of resulting exposure in the field.

The mouse absorbs a fraction of the parent compound together with some lipophilic metabolites formed in the gastrointestinal tract. None of these compounds pass the bloodbrain barrier or the barrier to the foetus. Excretion is relatively slow and dominated by the faecal route.

The high toxicity of certain saponins to fish has traditionally been ascribed to the demonstrated damage to the respiratory epithelia although also damage to the intestinal mucosa has been described. When it comes to snails and molluscs many, especially monodesmosidic, saponins are toxic at mg per litre concentrations; however, concerning the mode of action, only general speculations about the detergent effect on the soft body membranes have been presented. ${ }^{13)}$ Experiments with isolated (natural or artificial) membranes have disclosed a very complex structure-activity relationship. A majority of investigations points to monodesmosidic compounds as the most damaging, the composition of the target membrane, the structure of the aglycone and the saccharide moiety being important. ${ }^{13)}$ The present study used a mixture of deltonin with 25-isodeltonin, monodesmosidic saponins with a branched trisaccharide moiety. Further studies will have to disclose whether there are differences between the two isomers concerning the biological properties observed here, if the metabolites formed in the intestines of mice are identical to those found in snails, and whether the high toxicity to snails is due to the genuine compound(s) or to one or more of its more lipophilic metabolites.

\section{Acknowledgments}

The valuable help during the planning and project period of Director Dr. Asim Daffalla, Tropical Medicine Research Institute (NCR), Khartoum, as well as the scientific discussions with Dr. Mohammed El Wasila, Zoological Department, University of Khartoum, and with Drs. Mahgoub El-Tohami, and Ahmed K. Bashir, Medicinal Plant Research Institute (NCR), Khartoum, are kindly acknowledged. So is the great, both practical and theoretical, help of Director Niels Ørnbjerg and Dr. Henry Madsen from DBL (the Danish Bilharziasis Laboratory), Jægersborg and that of several other people from the staff of this institution. The whole-body autoradiography would never been a success without the great kindness of Dr. Tove Aas Jørgensen, Lundbeck Pharma, Valby, Denmark who is kindly thanked, as is Lundbeck Pharma for providing the facilities. The work was sup- ported by a grant from Danida, the Danish Ministry of Foreign Affairs.

\section{References}

1) G. Webbe: "Schistosomiasis, Epidemiology, Treatment and Control," ed. by P. Jordan and G. Webbe, William Heinemann Medical Books, London, pp. 1-50, 1982.

2) D. D. Bowman, R. C. Lynn and M. L. Eberhard: "Georgis' Parasitology for Veterinarians," 8th ed., Saunders, St. Louise, 2003.

3) R. Berkow and A. J. Fletcher (eds.): "The Merck Manual of Diagnosis and Therapy," 15th ed., Merck, Rahway, N.J., 1987.

4) P. Jordan and G. Webbe: "Human Schistosomiasis," William Heinemann Medical Books, London, 1982.

5) http://www.who.int/wormcontrol/en/action_against-worms.pdf

6) M. M. Kady, L. Brimer, P. Furu, E. Lemmich, H. M. Nielsen, S. T. Thiilborg, O. Thastrup and S. B. Christensen: Planta Med. 58, 334-337 (1992).

7) S. A. M. Abdelgaleil, A. F. El-Aswad and M. Nakatani: Pest. Manag. Sci. 58, 479-482 (2002).

8) A. W. Wanyonyi, S. C. Chhabra, G. Mkoji, U. Eilert and W. M. Njue: Phytochemistry 59, 79-84 (2002).

9) K. Hostettman, H. Kizu and T. Tomimori: Planta Med. 44, 34-35 (1982)

10) A. Marston and K. Hostettman: Phytochemistry 24, 639-652 (1985).

11) K. Hostettman: Naturwissenschaften 71, 247-251 (1984).

12) K. E. Mott: "Plant Molluscicides," John Wiley \& Sons Ltd., Chichester, 1987.

13) G. Francis, Z. Kerem, H. P. S. Makkar and K. Becker: $B r . J$. Nutr. 88, 587-605 (2002).

14) R. G. Archibald: Trans., Roy. Soc. Trop. Med. Hyg. 27, 207-210 (1933).

15) S. J. Pretorius, P. H. Joubert and A. C. Evans: S. Afr. J. Sci. 84, 201-202 (1988)

16) V. N. Okwuosa, B. S. Molta and S. Ebele: Appl. Parasitol. 34, 89-94 (1993).

17) M. Hosny, T. Khalifa, I. Calis, A. D. Wright and O. Sticher: Phytochemistry 31, 3565-3569 (1992).

18) M. S. Kamel: Phytochemistry 48, 755-757 (1998).

19) H. W. Liu and K. Nakanishi: Tetrahedron 38, 513-519 (1982).

20) C. O. Adewunmi and L.-E. Appelgren: Toxicol. Environ. Chem. 19, 199-216 (1989).

21) J. D. H. Lambert, J. H. M. Temmink, J. Marquis, R. M. Parkhurst, C. B. Lugt, E. Lemmich, W. L. Yohannes and D. De Savigny: Regul. Toxicol. Pharmacol. 14, 198-201 (1991).

22) P. Mølgaard, A. Chihaka, E. Lemmich, P. Furu, C. Windberg, F. Ingerslev and B. Halling-Sørensen: Regul. Toxicol. Pharmacol. 32, 248-255 (2000)

23) J. Ndamba, I. Robertson, E. Lemmich, S. K. Chandiwana, P. Furu and P. Mølgaard: Econ. Bot. 50, 151-166 (1996).

24) J. Ndamba, S. K. Chandiwana and N. Makaza: Acta Trop. 46, 303-309 (1989).

25) I. Slacanin, A. Marston and K. Hostettmann: J. Chromatogr. 448, 265-274 (1988).

26) S. T. Thilborg, S. B. Christensen, C. Cornett, C. E. Olsen and E. Lemmich: Phytochemistry 32, 1167-1171 (1993).

27) C. Perret, J.-L. Wolfender and K. Hostettmann: Phytochem. 
Anal. 10, 272-278 (1999).

28) J. Duncan and R. F. Sturrock: "Plant Molluscicides," ed. by K. E. Mott, John Wiley and Sons Ltd., New York, p. 257,1987.

29) D. C. Jain: Phytochemistry 26, 2223-2225 (1987).

30) Y. Watanabe, S. Sanada, Y. Ida and J. Shoji: Chem. Pharm. Bull. 31, 3486-3495 (1983).

31) I. S. Vasileva and V. A. Paseshnichenko: Appl. Biochem. Micro- biol. 31, 206-209 (1995).

32) V. A. Paseshnichenko and I. S. Vasileva: Appl. Biochem. Microbiol. 31, 66-72 (1995).

33) L. Brimer, S. B. Christensen, P. Mølgaard and F. Nartey: J. Agric. Food Chem. 31, 789-793 (1983).

34) Y. Yoshiki, S. Kudou and K. Okubo: Biosci. Biotechnol. Biochem. 62, 2291-2299 (1998). 